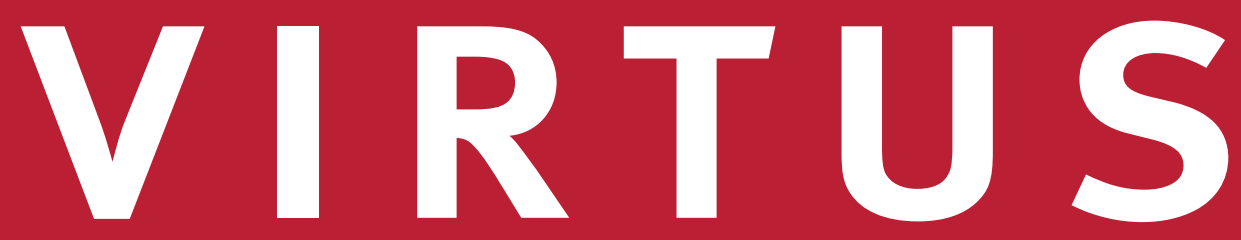

$27 \mid 2020$

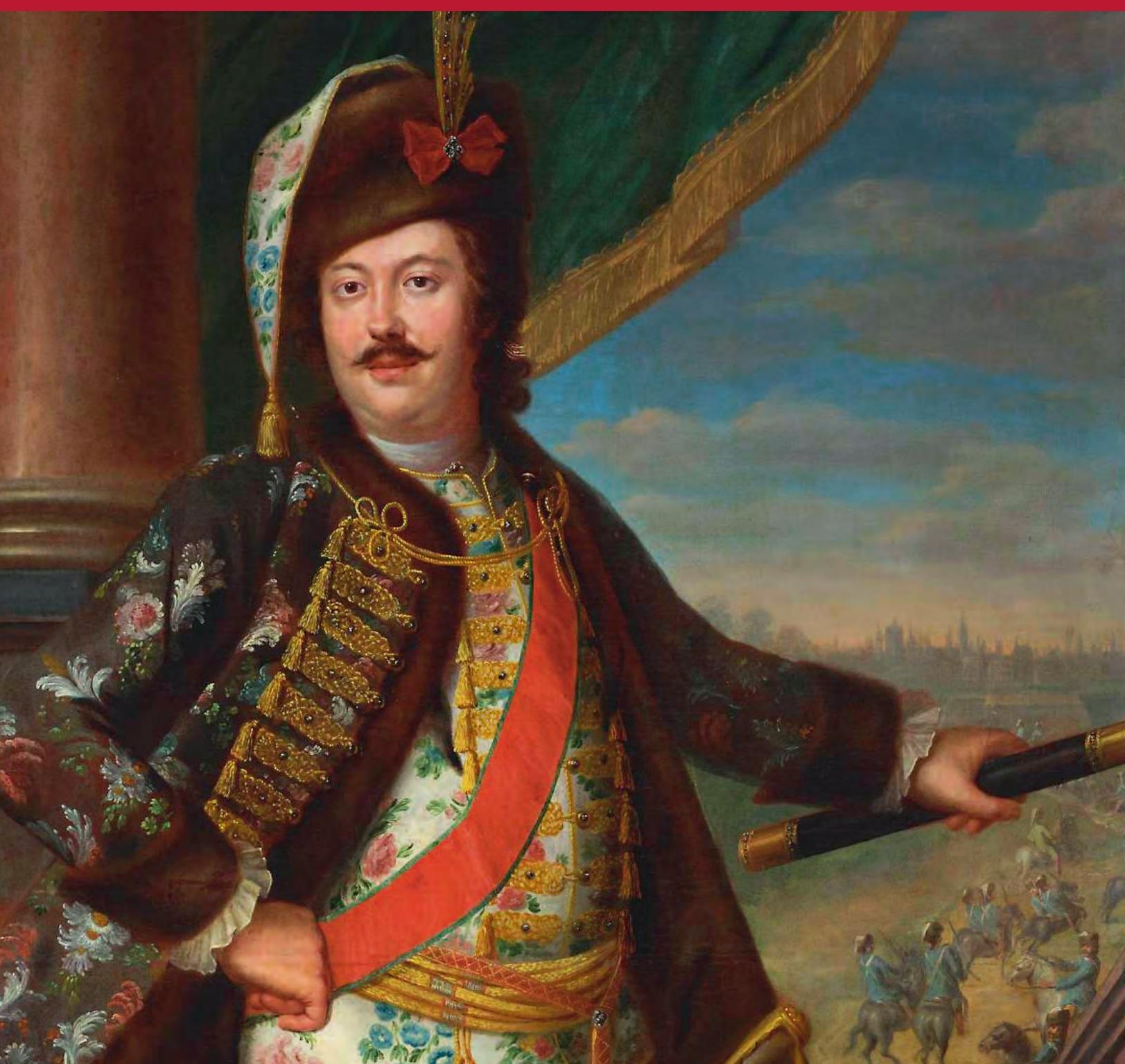




\section{Colin Veach}

\section{The structure of aristocratic society in England and Tuscany}

Peter Coss, The aristocracy in England and Tuscany, 1000-1250 (Oxford: Oxford University Press, 2020, 499 p., ill., index)

There can be few English historians who, while trudging to work on a murky winter's morning, have not dreamed of research that might take them to a Mediterranean climate. In this sense, Peter Coss' new book on the aristocracy in England and Tuscany carries with it the seasonal aspirations of an entire field. In it, Coss provides a synthesis of Italian scholarship on the Tuscan aristocracy, and then applies insights gleaned from it to aristocratic society in England. In so doing, he hopes 'to challenge the interpretive framework within which much English history of this period tends to be written' (2). In particular, Coss takes aim at historians who write what he describes as a 'somewhat diluted' Whiggish narrative of English history 'which revolves around Magna Carta and English exceptionalism' and posits a combative relationship between crown and aristocracy (2). Coss is fairly reticent about identifying the proponents of this view, but in later chapters his main targets appear to be James Campbell and John Maddicott. Whether or not they represent the current state of English historiography for this period is a moot point.

After an introductory Chapter 1 framing the study, Part I draws upon an extensive historiography to describe the power, preoccupations and social gradations of the Tuscan aristocracy. Chapter 2 provides a useful overview of Tuscan history from the disintegration of the Italian kingdom in the long tenth century to the rise of the major cities of Florence, Pisa and Siena by the mid-thirteenth. Here, as elsewhere, Coss is keen to emphasise the interplay between rural land-based lordship and urban communities. This is the focus of Chap- 
ter 3, which takes Florence and its contado (the Fiorentino) as a case study. Coss explores the cut and thrust of Florentine high politics and the movement of aristocrats from the city to the countryside and back. He relies heavily here on the work of Maria Elena Cortese, particularly her concept of an aristocrazia intermedia sitting below the level of the marquises, counts and other magnates but above well-off freemen. This social layer is further subdivided into those who were multi-zonal (holding lands scattered across the contado and participating in the life of the city), and those who were zonal (more or less restricted to rural property in one area). In the end Coss agrees with Cortese that the aristocrazia intermedia's gravitation on the city kept it and the contado in constant contact until a late-eleventh century crisis of public institutions deprived many of its members of their urban benefactors. Forced to find new means of support, they turned their backs on the city in favour of rural lordship.

Chapter 4 uses Pisa as a case study in the aristocrazia consolare, since it was the first city in Tuscany to have moved to rule by consuls. This is a wide-ranging chapter, taking in, among other things, the military proclivity of the city and its rulers, as well as its related interests in maritime commerce. Coss finds an opportunistic and enterprising aristocracy, willing to take chances and exploit public office to their advantage. He notes a tension between these somewhat selfish interests and a communitarian feeling focused on the city. Chapter 5 looks beyond the city to the world of the rural aristocracy. This focuses primarily on the comital house of Guidi, who, through a combination of public authority, intensive lordship, and a network of strategically placed castles, attempted to build a principality virtually encircling the city of Florence. In Chapter 6 the focus shifts to southern Tuscany, where the 'ban' (authority to order and punish) was less socially restricted and the peasantry were more widely dependent than in the north. Here Coss is able to pay more attention to the entry into the aristocracy of families from the city of Siena, which saw bankers granted castles taken from local lords in the city's relentless expansion of its authority. Chapters 7 and 8 focus on the social forces acting upon the Tuscan aristocracy. Chapter 7 emphasises a perceived tendency towards social equilibrium amidst a general propensity for violence and the practical need for security. He also charts a descent of the 'ban' to castellans, akin to what Georges Duby discerned in the Mâconnais. Chapter 8 deals with the significance of knighthood and the crystallisation of an exclusive nobility in Tuscany. Coss follows the basic outline for the evolution of a more exclusive knighthood proposed by Jean Flori. However, he argues for a local materialistic cause to this social distancing in Tuscany, based on the crisis of cities flooded with new wealth and immigrants, rather than a diffusion of French ideology into the region.

In Part II, Coss examines English aristocratic society. Chapters 9 and 10 look at England either side of the Norman Conquest. Among other things, Coss brings Cortese's structuralist interpretation of the Tuscan aristocracy to bear upon the English evidence. The result is quite striking. By conceiving of English thegns and knights as members of an aristocrazia intermedia, with its emphasis on zones of power rather than vertical feudo-vassalic relationships, other forms of clientship and horizontal association become more apparent. In Chapter 11, Coss makes further good use of his new perspective in a perceptive case study of the earls of Chester. Part II is rounded off with a chapter on the nobility and state in Angevin 
England, in which Coss emphasises power relations rather than a developing English constitution. Here, Coss finally gets to argue with Maddicott about the origins and impact of Magna Carta, and to summarise his theory of the origins of the English gentry. The book ends with a concluding Chapter 12.

As with any innovative study, there are points with which some readers will take issue. For instance, Coss' tendency towards historical materialism will likely ruffle the feathers of historians working on more ideological studies of nobility. His attack on constitutionalism might also put a few historians of late medieval England on edge. One of the more nagging issues for this reviewer, however, concerns the study's shifting framework. In Part I, the focus is clearly on the region of Tuscany - to the exclusion, for instance, of the Guidi's interests across the border in Romagna. In Part II, however, Coss switches between a regional study of the English Midlands and one encompassing the entire kingdom of England. Coss' analysis in Part II is most effective in his case studies focusing on Warwickshire (part of Chapter 10) and the earls of Chester (Chapter 11). In these sections, as in the Tuscan chapters, Coss engages with studies of the regional aristocracy and individual aristocrats to give a real sense of the aristocratic experience of power and social standing on the ground. When he broadens his framework to encompass all of England (Chapters 9, 10 and 12), however, the historiography with which he engages is dominated by national studies that focus on the crown, its institutions, and a community of the realm. This may seem a natural focus to some, but it is not a neutral one. The earls of Chester, for instance, held lands in England, Normandy and Wales, and controlled one of the Irish Sea's main hubs of trade and communication. Their interests certainly stretched beyond the Midlands (as the Guidi's did beyond Tuscany), but they were not bound by the administrative borders of England. Coss warns us that 'we should be aware that our sources encourage us to place too much emphasis on the king's perspective' (282), but the same might be said regarding the state's perspective. By accepting the kingdom of England as its aristocracy's natural purview, in a way that he does not accept Italy or the Empire for the Tuscan aristocracy, Coss risks reinforcing the state-centred approach to English history he seeks to disrupt.

Here, Coss' decision not to engage with the 'new British' history of Rees Davies and others is felt most keenly. Davies anticipated Coss' attack on 'the making of England' by over three decades, and offered in its place a decentralised 'matter of Britain' based on orbits of power and obligation. This is not to suggest that Coss ought to have authored a study on 'Britain and Tuscany', but rather that in going beyond the Midlands he might have benefitted from engaging with studies that place the English aristocracy in its transnational context, emphasise the multifaceted nature of lordship at local and regional levels, and downplay the importance of the state. To these 'British' works can be added a number of more traditionally English studies which focus on individual families, regions or aristocrats. These are perhaps not as prominent as studies claiming kingdom-wide relevance or positing overarching models for medieval polities, but, as Coss' own case studies show, they would constitute invaluable building blocks for a study of the English aristocracy on its own terms.

Despite these complaints, Coss is to be praised for authoring a useful study. His synthesis of Italian work on the Tuscan aristocracy is invaluable to historians (such as this reviewer) who lack the linguistic skills to approach it independently. His conception of English 
knights as an aristocrazia intermedia adds weight to arguments emphasising multiple forms of clientship as well as horizontal ties of lordship, neighbourhood and collective interests. Finally, his depiction of the aristocracy in both England and Tuscany as active participants in public authority chimes well with recent studies emphasising cooperation over competition at the top of medieval political society.

University of Hull - c.veach@hull.ac.uk 
Valbijl of vangnet? Natuurmonumenten, de adel en de verwerving van landgoederen en buitenplaatsen, 1905-1980

Class, gender and national identity. Music-making in eighteenth-century Dutch noble homes

Joris van Son

Insignia Summorum Principum. Using symbols of power in pursuit of higher rank and status by German prince-electors and Polish-Lithuanian princes Jakub Rogulski

\section{Dossier Adellijke Vrouwen}

'Defending the castle like a man': on belligerent medieval ladies Elizabeth den Hartog

Belle van Zuylen: schrijfster van adel, over de adel. Haar correspondentie digitaal beschikbaar

Suzan van Dijk

Een ruk naar Brits. De internationale politiek van Anna van Hannover, 1756-1757 Simone Nieuwenbroek 